\title{
Response of a littoral macroinvertebrate assemblage to a persistent hydrological drought in a permanent mountain shallow lake from northwestern Spain
}

\author{
Adrián Villastrigo ${ }^{1,2, *}$ and Francisco García-Criado ${ }^{2}$ \\ ${ }^{1}$ Institute of Evolutionary Biology, Passeig Marítim de la Barceloneta 37-49, 08003 Barcelona, Spain \\ 2 Area of Ecology, Faculty of Biology and Environmental Science, University of León, Campus de Vegazana s/n, 24071 León, Spain
}

Received: 25 February 2016; Accepted: 10 July 2017

\begin{abstract}
Current projections predict an intensification of hydrological drought as a consequence of climate change, but we know very little about the potential effects on aquatic communities. La Baña (SW León Province, Spain) is a mountain lake suffering from increased water seepage due to geological reasons. This has caused since 2005 a situation of hydrological drought, with pronounced reduction of lake area in late summer. The aim of this study was to assess the effects of this drought on the littoral macroinvertebrate assemblage. Macroinvertebrate samples were collected in 2005 (before the drought events became apparent), 2006 and 2014, as well as in a nearby temporary pond (only in 2014). The most evident change shown by the assemblage at La Baña was a drop in richness values. Rarefaction curves showed that richness in the lake in 2014 was, for an equivalent sampling effort, only slightly higher than that in the temporary pond, and much lower than that in the lake in 2005 or 2006 . However, the assemblage composition did not shift toward a fauna typical of temporary waterbodies. The results might indicate that the resistance of the assemblage was high enough to prevent changes in the first moments (differences between 2005 and 2006 were small), but not after nine years of sustained summer drought.
\end{abstract}

Keywords: summer drought / mountain lakes / littoral macroinvertebrates / richness / global change

\section{Introduction}

The characteristics of freshwater ecosystems, like the availability of water or the exposition to anthropogenic stressors, make them particularly vulnerable to climate change (Woodward et al., 2010). The scenarios of climate change for the 21 st century predict a widespread temperature increase over the planet, but the projections of future changes in precipitations are far less consistent. In general, a decline in annual mean precipitations is expected in subtropical and midlatitude (including southern Europe) regions, especially on the long term (Collins et al., 2013). This will lead to reduced runoff and increased evaporation. Thus, one of the most evident effects of climate change in certain regions will be the reduced river flows or lake water levels, that is, hydrological drought as defined by Lake (2011). That is the case of southern and central Europe, where a tendency for drought intensification is expected (Seneviratne et al., 2012).

Our knowledge about the effects of drought on aquatic systems has greatly improved in the last few decades, but is markedly biased toward river ecosystems (Lake, 2003) as

\footnotetext{
$\bar{*}$ Corresponding author: adrian.villastrigo@ibe.upf-csic.es
}

shown by reviews on the subject (Bond et al., 2008; Lake, 2011). The information referring to standing waters is sparse (e.g. James, 1991; Nõges and Nõges, 1999; Beklioglu and Tan, 2008), and predominantly on biotic effect (Lake, 2011). Hydrological drought has a number of known effects on the abiotic characteristics of waterbodies (e.g. increased conductivity, more exposure of littoral zones, reduction of plant cover, decline nutrient inputs, etc., see Lake, 2011 for a review) which might have implications on the biological communities. Among these, littoral benthic macroinvertebrates are a key component of aquatic communities as intermediate links between producers and higher levels of trophic chains, and have been considered good indicators of climate change or, more specifically, of temperature increase (ČiamporováZatovičová et al., 2010). We have some knowledge about the response of river macroinvertebrates assemblages to drought (Boulton, 2003; Griswold et al., 2008; Boix et al., 2010; Chessman, 2015), but very little referring lakes or ponds. Some interesting contributions are the studies by Jeffries (1994) about artificial ponds, Mackay et al. (2010) in estuarine lakes or Chase (2007) and Kim et al. (2014) in experimental ponds or mesocosms, and Gérard (2000) in a macroinvertebrate study after a several drought event, as well as the works 


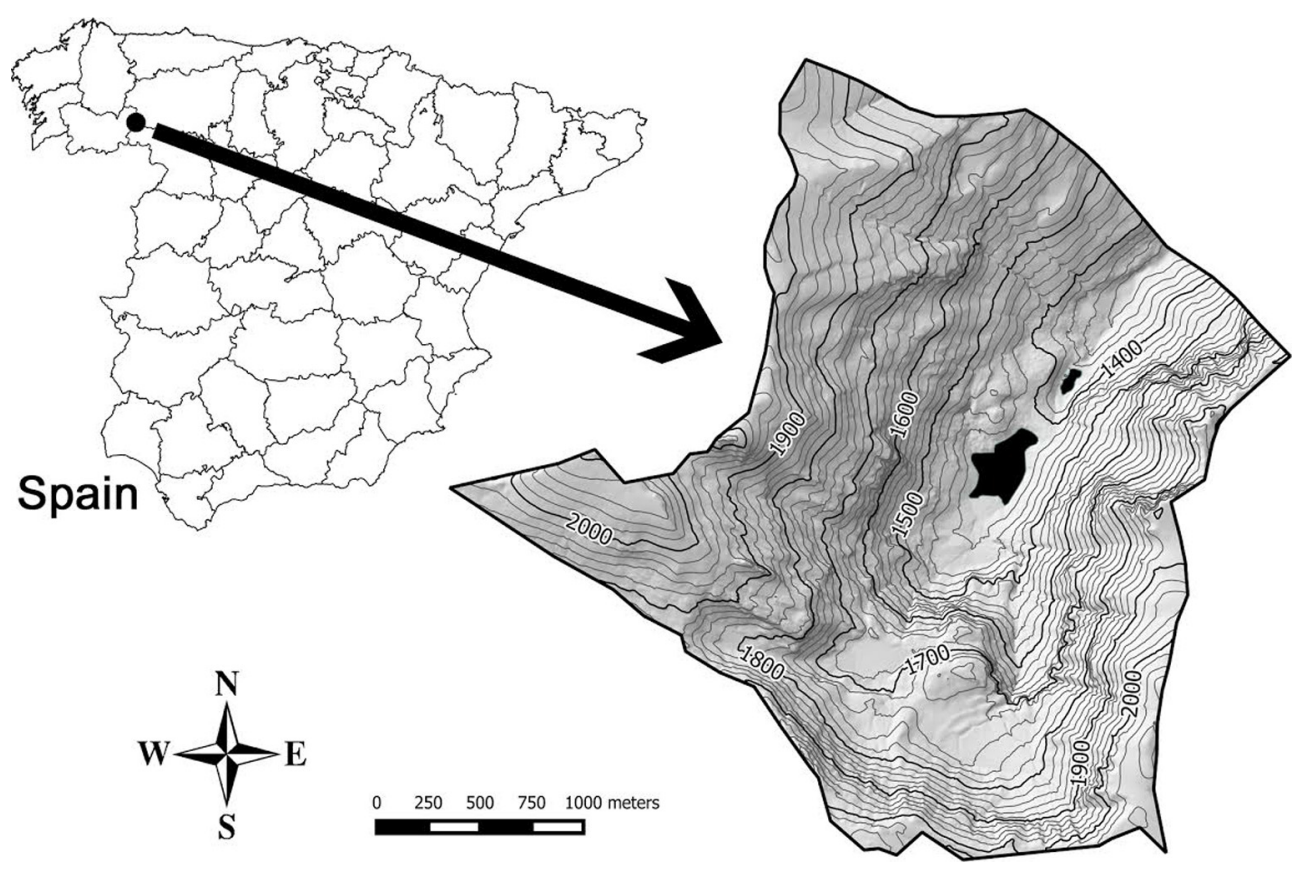

Fig. 1. Location of the study area. The detailed map shows the position of Lake La Baña and of the small temporary pond next to it.

by Gérard (2001) and Balogh et al. (2008) on particular taxa. The effects of drought on pond macroinvertebrates reported by these authors are often reduced richness, changes in taxonomical composition or both at the same time. However, these studies provide partial information from particular types of ecosystems and geographical areas. Our current knowledge suffers from gaps or imperfections which should be solved. For example, we know very little about the long-term effects of drought on communities from natural lakes or ponds, especially in mountain waterbodies.

La Baña is a mountain shallow lake in northwestern Spain which is suffering from geologically-induced water depletion since 2005. The most evident consequence is water-level drawdown and reduced flooded area in summer. The situation is that of a summer hydrological drought caused by water abstraction (Lake, 2011) and might mimic to some extent the effects of drought induced by climate change. This can provide us with information on the response of macrobenthic communities to drought in a natural ecosystem, a task so far undertaken mostly in mesocosms or artificial ponds (Jeffries, 1994; Chase, 2007; Kim et al., 2014; but see Gérard, 2000 for a study in natural ponds). The aim of this research was to study the response of the littoral macroinvertebrate assemblage to a persistent hydrological summer drought in a mountain shallow lake. Increased water level fluctuations and summer stress might create conditions similar to some extent to those in highly fluctuating (or even temporary) systems and induce changes in the macroinvertebrate assemblage (i.e. abundance, richness and taxonomical composition). Firstly, some taxa might be removed causing richness to decrease, as reported for fluctuating systems (Aroviita and Hämäläinen, 2008) or subjected to drought (Jeffries, 1994; Gérard, 2000). In fact, it is widely believed that the shorter the hydroperiod length, the lower the richness (Spencer et al., 1999; Waterkeyn et al., 2008). Similarly, temporary ponds are often less species- rich than the permanent one (Nicolet et al., 2004), although different outcomes have also been reported. For instance, Galindo et al. (1994), in planktonic crustacean assemblages, found higher richness values in temporary ponds whereas Boix et al. (2008) found no significant differences in richness of invertebrates (crustacean and macroinvertebrates) from Mediterranean water bodies. The consequence of this loss of taxa is that macroinvertebrate assemblages in temporary ponds are often a subset of nearby permanent systems (Bazzanti et al., 2000; Wissinger et al., 2016). Secondly, conditions created during summer drought might favor species with certain biological traits, in particular those typical of taxa inhabiting temporary systems, as found by Chessman (2015) for river macroinvertebrates. This can lead to a shift in taxonomical composition. Therefore, we expected a decline in richness, a partial taxon turnover in our study area and changes on abundance. Such changes could make the assemblage of $\mathrm{La}$ Baña (or some of its features) more similar to that of a temporary pond.

\section{Methods}

\subsection{Study area}

La Baña is a Mediterranean mountain lake (1400 m a.s.l.) lying on a quaternary glacial cirque in the southwest of the province of León, in northwestern Spain (Fig. 1). It is included in the Nature 2000 network, Birds Directive Sites ES4130024. It is a shallow water body (maximum depth in summer usually around $2 \mathrm{~m}$ ) with maximum flooded area seldom above 6 ha (in springtime, after snowmelt). The littoral zone near the shore (up to a depth of $70 \mathrm{~cm}$ ) has a heterogeneous substrate granulometry, including areas dominated by silt, gravel, cobbles or boulders. Most of it is covered by sparse vegetation dominated by Isoetes, Callitriche and Antinoria. 
Although it is a permanent system, it has experienced extremely low water levels since summer 2005, when it almost dried up for the first time. The true reason for this water drawdown is currently under research, but it is probably due to increased water seepage caused by a geological fracture, perhaps created by the mining activities in progress $1 \mathrm{~km}$ downstream the lake. This has resulted in unusually low flooded area in late summer, as shown in Table 1, which gives the values of flooded area after snowmelt (maximum water level), and in the first half of September (when the water level is at its lowest) as measured from Landsat satellite imagery. The percentage of intra-annual area reduction (expressed in percentage) is also provided in the table. The values of minimum flooded area were significantly lower in the period 2005-2013 than that in 1999-2004 (ANOVA, $F_{(1,13)}=16.6$, $p=0.001$ ). Maximum flooded area in spring, however, has not been affected (ANOVA, $F_{(1,11)}=0.003, p=0.96$ ). Therefore, the current situation of La Baña is that of a lake subjected to long-term, hydrological drought, which manifests itself in reduced lake area in summer and increased annual water-level fluctuation. Physical and chemical characteristics of the lake did not substantially change throughout the study (Tab. 2).

In the course of the research, we also sampled a small (around $0.7 \mathrm{ha}$ ) very shallow, temporary pond which is $200 \mathrm{~m}$ downstream the lake. The aim of this sampling was to describe the community composition in a temporary pond in the same area and date. This information was only intended to test whether the characteristics of the macroinvertebrate community in the lake turned similar in some degree, after increased summer drought, to that of a temporary system.

\subsection{Sampling of macroinvertebrates}

Data were collected in Lake La Baña in June 2005, 2006, and 2014, providing information on the situation of the lake at three stages: before the drought set in, early stage of the drought and current state. In all three occasions, littoral macroinvertebrate samples were collected by kicking and sweeping with a hand-net (FBA standard) following a multihabitat sampling. The littoral zone (up to a depth of $70 \mathrm{~cm}$ ) was sampled during $4 \mathrm{~min}$ proportionally distributed among the dominant mesohabitats according to their area. The same zones and mesohabitats of the lake were sampled on each visit. Furthermore, a 1-min sampling was undertaken in the temporary pond in June 2014 using the same technique as in the lake. Sampling time in the pond was kept short to avoid comparative oversampling of a waterbody much smaller and with less habitat heterogeneity than the lake. The data taken in each waterbody and year were pooled together to form a single sample. Therefore, four samples have been considered in this study: lake 2005 (L2005), lake 2006 (L2006), lake 2014 (L2014), and pond 2014 (P2014).

The macroinvertebrates were sorted out at the laboratory. When necessary, subsamples were taken until at least 600 specimens were collected. In this case, an additional search for new, rare taxa was made on the rest of the sample in order to get a more accurate record of richness. Abundances were corrected for subsampling effort to estimate total number of individuals per sample and finally expressed as number of individuals per minute sampling. Taxa were identified to genus level except for Oligochaeta (to class), Diptera (mostly to subfamily), and
Table 1. Maximum and minimum flooded area in La Baña from 1999 to 2013. Minimum area was measured in the first half of September (when the water level is at its lowest). Maximum area was measured in April or May, after snowmelt, excepting 1999 and 2012 (images not available).

\begin{tabular}{llll}
\hline Year & $\begin{array}{l}\text { Max. area } \\
\text { (ha) }\end{array}$ & $\begin{array}{l}\text { Min. area } \\
(\text { ha })\end{array}$ & $\begin{array}{l}\text { Area reduction } \\
(\%)\end{array}$ \\
\hline 1999 & - & 1.57 & - \\
2000 & 5.8 & 1.51 & 74 \\
2001 & 6.1 & 0.56 & 91 \\
2002 & 5.4 & 0.98 & 82 \\
2003 & 5.7 & 0.55 & 90 \\
2004 & 5.2 & 0.80 & 85 \\
2005 & 4.3 & 0.33 & 92 \\
2006 & 4.9 & 0.17 & 97 \\
2007 & 5.4 & 0.69 & 87 \\
2008 & 5.1 & 0.19 & 96 \\
2009 & 5.8 & 0.26 & 95 \\
2010 & 6.7 & 0.46 & 93 \\
2011 & 6.0 & 0.21 & 97 \\
2012 & - & 0.25 & - \\
2013 & 7.1 & 0.42 & 94 \\
\hline
\end{tabular}

Table 2. Physical and chemical characteristics in La Baña during the study period. Measurements were made in June.

\begin{tabular}{llllll}
\hline Year & $\begin{array}{l}\text { Conductivity } \\
(\mu \mathrm{S} / \mathrm{cm})\end{array}$ & $\mathrm{pH}$ & $\begin{array}{l}\text { Oxygen } \\
(\mathrm{mg} / \mathrm{l})\end{array}$ & $\begin{array}{l}\mathrm{TN} \\
(\mathrm{ppm})\end{array}$ & $\begin{array}{l}\mathrm{TP} \\
(\mathrm{ppb})\end{array}$ \\
\hline 2005 & 10.2 & $\mathrm{NM}$ & $\mathrm{NM}$ & 0.09 & 41.20 \\
2006 & 9.0 & 6.2 & 7.3 & 0.44 & 29.04 \\
2014 & 9.3 & 6.3 & 8.2 & 0.68 & 15.20 \\
\hline
\end{tabular}

$\mathrm{NM}=$ not measured, $\mathrm{TN}=$ total nitrogen, $\mathrm{TP}=$ total phosphorus.

Trichoptera (to tribe). Adult Coleoptera were identified to species following Millán et al. (2014), but they were considered at genus level for statistical purposes.

\subsection{Statistical analysis}

For comparisons of community composition, log-transformed abundance data (individuals per minute sampling) were used in a Non-metric Multidimensional Scaling (NMDS) analysis, based on Bray-Curtis similarity matrix and performed in $\mathrm{R}$ version 3.1.3. The maximum taxonomical resolution was used except for beetles, which were considered at genus level - this same procedure was applied in other ecological studies in the same region (Martínez-Sanz et al., 2012; García-Criado et al., 2017).

In order to check whether differences in the taxonomical composition were due to a replacement or to a loss of taxa, we calculated $\beta$ diversity between pairs of samples and its partition into two components: species turnover and nestedness. Following Baselga (2010), the Sørensen pairwise dissimilarity index was used as a measure of $\beta$ diversity 
$\left(\beta_{\text {sor }}\right)$, species turnover was described by Simpson pairwise dissimilarity $\left(\beta_{\text {sim }}\right)$, and nestedness $\left(\beta_{\text {nes }}\right)$ was calculated as $\beta_{\text {sor }}-\beta_{\text {sim. }}$. To clearly summarize in a single value, the contribution of these components to $\beta$ diversity, we have calculated the proportion of $\beta_{\text {sor }}$ corresponding to nestedness $\left(\beta_{\text {nes }} / \beta_{\text {sor }}\right)$. Nestedness analysis was made using betapart R-package (Baselga and Orme, 2012).

Comparisons of taxon richness across sites can be compromised by differences in sampling effort, particularly between the pond and the lake. Therefore, a rarefaction method was applied in order to estimate the expected richness value for a common sample effort (Colwell et al., 2012). Rarefaction was made on number of specimens using the software iNEXT (Hsieh et al., 2013).

\section{Results}

\subsection{Community composition}

Twenty-six genera and nine higher taxa were recorded in the study, and fourteen species of Coleoptera were identified (Appendix). The lake was dominated by Siphlonurus and, secondarily, by Hydroporus vagepictus and Chironominae subfamily in any year. Siphlonurus relative abundance was exceptionally high in 2014 with respect to previous years, while $H$. vagepictus seems to show no changes over time. The assemblage in the temporary pond differed markedly from that of the lake and was dominated by the three subfamilies of Chironomidae (Chironominae, Tanypodinae and Orthocladiinae) and secondarily by Agabus sp. and Helophorus lapponicus. Non-metric multidimensional scaling (Fig. 2) arranged the four samples in a two-dimensional space with a final stress of 0.0097 . NMDS showed an evident difference in community composition between the temporary pond and the lake. No evident differences in the assemblage were found between lake 2005 (pre-drought conditions) and 2006 (early stage of drought). Differences in the lake were somewhat larger between 2005-2006 and 2014, although many of the taxa found in 2014, and all the dominant ones, were also found in 2005 or 2006 (Appendix). Inter-annual differences were mostly due to the apparent loss in 2014 of some taxa which were relatively abundant in 2005 and 2006 (in particular Erpobdella, Pisidium, Sigara, Nebrioporus carinatus and Limnephilini, which were replaced by Stenophylacini), and to the occurrence, although in very low numbers, of four new taxa in 2014 (Ecdyonurus, Chloroperla, Leuctra, and Nemoura, all them four typically rheophilic).

\subsection{Species turnover and nestedness patterns}

The patterns shown by NMDS were confirmed by the Sørensen dissimilarity index: dissimilarity was low between L2005 and L2006 $\left(\beta_{\text {sor }}=0.24\right)$ and higher $\left(\beta_{\text {sor }} \geq 0.48\right)$ in the rest of the pairwise comparisons (Tab. 3). Changes at La Baña in 2014 can be mostly attributed to species turnover (when compared to 2005) or both species turnover and nestedness (in relation to 2006). When the above-mentioned rheophilic taxa were removed from the analysis, differences between 2014 and previous years were mostly (or completely for the pair L2014-L2006) due to nestedness. Both nestedness and species turnover equally contributed to $\beta$ diversity between P2014 and

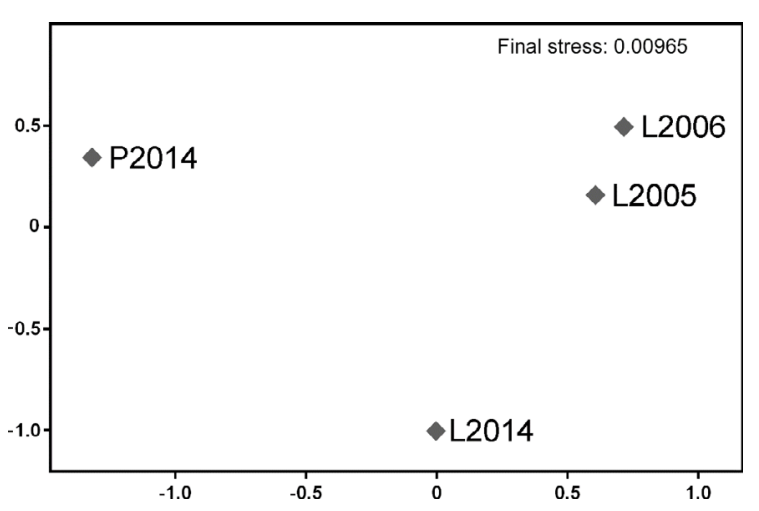

Fig. 2. Non-metric multidimensional scaling (NMDS) ordination for macroinvertebrate communities.

L2005 or L2006, but differences between P2014 and L2014 were mostly a result of species turnover.

\subsection{Community richness}

The most evident change shown by the assemblage at Lake La Baña was a richness decrease. In spite of the four new genera occurring in 2014 (see above), the number of taxa (genera or higher) recorded this year was 15, quite lower than the values recorded in 2005 (21) or 2006 (26). The number of taxa in the temporary pond was much lower (9), but so was the sampling effort. In order to make the results easier to compare, rarefaction curves according to the number of organisms collected were constructed for all the samples (Fig. 3). An overlap of the confidence intervals for 2005 and 2006 was observed, indicating that there were no differences in richness between those samples. Rarefied richness in the lake 2014 was only slightly higher than that of the temporary pond for the same sampling effort, and much lower than rarefied richness in 2005 or 2006 . The decline in richness at La Baña was very visible within Coleoptera: 8 species/genera were recorded in 2005, 11 in 2006 and only 3 in 2014.

\section{Discussion}

Increasing drought is a key feature of future scenarios of climate change in large areas of temperate regions (Seneviratne et al., 2012). The consequences on aquatic ecosystems of such tendency are far from understood, specially on continental standing water communities, and virtually nothing about its effect on mountain ponds. The most common approach to the problem has been through spatial studies comparing ponds with varying hydroperiod. There is no doubt that temporary and permanent ponds support different macroinvertebrate assemblages (Jeffries, 1994; Gérard, 2000; Della Bella et al., 2005), even in Spanish mountain areas (García-Criado et al., 2017). In general, species richness of macroinvertebrates typically increases with increasing hydroperiod (Collinson et al., 1995; Spencer et al., 1999; Della Bella et al., 2005; Waterkeyn et al., 2008). From these data, we may assume that the drought-driven desiccation of a pond or lake will imply severe alterations of the assemblage structure, with a substitution of taxa as well as marked decreases in richness in most cases. 
Table 3. Pairwise $\beta$ diversity (Sørensen dissimilarity, $\left.\beta_{\text {sor }}\right)$ and its partition into species turnover $\left(\beta_{\text {sim }}\right)$ and nestedness $\left(\beta_{\text {nes }}\right)$. The proportion of $\beta$ diversity caused by nestedness $\left(\beta_{\text {nes }} / \beta_{\text {sor }}\right)$ is also given. The values in parenthesis correspond to calculations after removing the rheophilic taxa (Ecdyonurus, Chloroperla, Leuctra and Nemoura).

\begin{tabular}{|c|c|c|c|c|c|c|}
\hline & \multicolumn{2}{|c|}{ L2005 } & \multicolumn{2}{|c|}{ L2006 } & \multicolumn{2}{|c|}{ L2014 } \\
\hline L2006 & 0.24 & $\begin{array}{l}0.14 \\
0.10 \\
0.42\end{array}$ & & & & \\
\hline L2014 & $0.51(0.44)$ & $\begin{array}{l}0.40(0.18) \\
0.11(0.26) \\
0.22(0.59)\end{array}$ & $0.48(0.40)$ & $\begin{array}{l}0.27(0.00) \\
0.22(0.40) \\
0.46(1.00)\end{array}$ & & \\
\hline P2014 & $0.61(0.59)$ & $\begin{array}{l}0.33(0.25) \\
0.28(0.34) \\
0.46(0.58)\end{array}$ & $0.68(0.65)$ & $\begin{array}{l}0.33(0.25) \\
0.34(0.40) \\
0.50(0.62)\end{array}$ & $0.50(0.47)$ & $\begin{array}{l}0.33(0.38) \\
0.17(0.10) \\
0.34(0.21)\end{array}$ \\
\hline
\end{tabular}

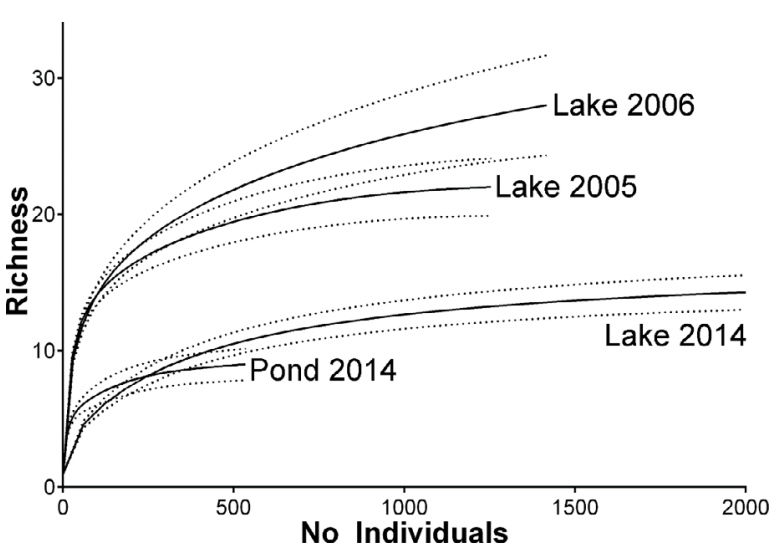

Fig. 3. Rarefaction curves for the four samples. Dashed lines show $95 \%$ bootstrap confidence lower and upper limits for the estimated rarefaction richness.

However, such spatial approaches leave several questions unanswered: (1) we do not know to which extent temporal patterns (changes in a pond subjected to drought or drying) reproduce the observed spatial differences (differences among ponds with varying hydroperiod) and (2) most of the abovementioned evidences come from studies comparing the extremes of a drying gradient (permanent versus temporary water bodies), but scenarios of climate change do not necessarily involve complete desiccation of lakes in summer. In such cases, the potential effects on littoral communities may come from two major alterations: changes in water quality driven by the low summer volume of the lake, and increased intra-annual fluctuations in water level. On the one hand, the reduction in volume and depth in a lake may lead to major changes in temperature regimes, turbidity, suspended solids, water chemistry and nutrient concentrations, as well as other biotic changes like fish kills, replacement of littoral vegetation, cyanobacteria blooms (related with an increased temperature) or increased predation and competition (Nõges and Nõges,
1999; Bond et al., 2008; Lake, 2011; Sahuquillo et al., 2012). On the other hand, an increase in the intensity of water level fluctuations can become a major stressor for the littoral zone and could explain by itself differences in community composition, including macroinvertebrates. This effect has been demonstrated in both artificially regulated systems (Furey et al., 2006; Aroviita and Hämäläinen, 2008) and natural lakes affected by drought (Wantzen et al., 2008; White et al., 2008). Modification of the natural regime of water-level fluctuations has traditionally been considered the main stressor and, indeed, most studies have focused on the effects of desiccation of the littoral zone and disregarded water quality changes. Nevertheless, the individual effects of both aspects can simultaneously affect macroinvertebrates, as proposed by Gérard et al. (2008).

Both types of change, in water quality and water-level fluctuations, might affect littoral communities at La Baña, although we lack environmental data to confirm the alteration of the water characteristics in late summer. The composition of the macroinvertebrate assemblage did not experience essential modifications: dominant taxa before and after the beginning of the drought were to a large extent the same and there was not a shift toward a fauna typical of temporary waterbodies. Nevertheless, the analysis of $\beta$ diversity revealed both a loss of taxa and taxon turnover in La Baña along time. The replacement of Limnephilini by Stenophylacini, the apparent extinction of Erpobdella, Pisidium, Sigara and N. carinatus, and the presence in 2014 of Ecdyonurus and three genera of Plecoptera were the most outstanding changes. This result apparently supported our hypothesis of changes in both richness and taxonomical composition. However, it is noteworthy that taxon turnover was mostly due to Ecdyonurus and the genera of Plecoptera (Chloroperla, Leuctra and Nemoura), all them four typically (but not exclusively) rheophilic taxa (Tierno de Figueroa et al., 2003; Bauernfeind and Soldán, 2012), and very infrequent in mountain lakes of the region. Their occurrence in La Baña in 2014 might be the result of accidental influence from the inflowing stream and 
should probably be taken as sampling bias. If the occurrence of these four taxa was really due to sampling bias, we should interpret the differences in the assemblage composition between 2014 and 2005-2006 mostly as a process of taxon loss with little taxon turnover.

The patterns of response of individual macroinvertebrate taxa to increased water-level fluctuations or to drought are still little known and the results are not consistent across studies, indicating that varying starting conditions or species may lead to different outcomes. This makes it difficult to explain the observed shifts in individual taxa. There is some agreement about the sensitivity of sessile or sedentary organisms to declining water levels (Lake, 2011), as shown for bivalves (Balogh et al., 2008; Werner and Rothhaupt, 2008) or gastropods (Gérard, 2001; Gérard et al., 2008). The absence of Pisidium in La Baña in the samples collected in 2014 could therefore be an expected outcome. Nevertheless, generalizations are difficult for most of the taxa. For example, Aroviita and Hämäläinen (2008), comparing unregulated and regulated lakes, found a number of taxa within Ephemeroptera, Coleoptera and Trichoptera to be good indicators of unregulated lakes, but none typical of regulated ones. In contrast, Furey et al. (2006) found Ephemeroptera in a reservoir lake but not in a natural lake. Similarly, species of beetles, the most diverse insect order in our study, show varying responses which prevent generalizations. We found a considerable reduction along time in the number of genera of Coleoptera in La Baña, in accordance with the observations made by Aroviita and Hämäläinen (2008) on systems with different water-level fluctuations. However, many water beetle species are known to tolerate high water-level fluctuations or temporary drying, and richness of Coleoptera is in fact typically high in temporary ponds (Collinson et al., 1995; Bazzanti et al., 2003; Della Bella et al., 2005; Waterkeyn et al., 2008).

In summary, the interpretation of the patterns observed for individual taxa is not straightforward. It is very likely that finding global patterns comparable across regions require approaches other than taxonomic composition, whether based on species traits (Solimini et al., 2005; Céréghino et al., 2012) or on community measures such as richness. In La Baña, richness decline was the most evident response to drought, with a decrease of $29 \%$ and $42 \%$ in relation to values measured in 2005 and 2006, respectively. When richness was rarefied to account for differences in sampling effort, after-drought (year 2014) values (but not pre-drought values) were very close to those in a nearby, temporary pond. In summary, the macroinvertebrate assemblage at La Baña did not shift toward a fauna typical of temporary waterbodies but richness did drop to values closer to those in temporary systems. Changes in richness are common in spatial studies comparing water bodies with different patterns of water-level fluctuations (Aroviita and Hämäläinen, 2008) or hydroperiod (see above), but it remains to be checked if a given water body suffering from a drought event shows an equivalent response. A decrease in macroinvertebrate richness will almost certainly occur when a permanent or semi-permanent lake goes completely dry, but the outcome might be quite different if the water body does not dry up (Jeffries, 1994). The results obtained in La Baña point to macroinvertebrate richness decrease even in the absence of complete drying, as found by White et al. (2008), who could relate changes in richness with inter-annual differences in the intensity of water-level fluctuations.
Our results seem to challenge previous statements made by Biggs et al. (1994) and Collinson et al. (1995), who considered that a normally permanent pond could temporarily dry out without evident consequences on the assemblages. Resistance and resilience of the community are certainly critical issues (Brock et al., 2003; Bond et al., 2008; Gérard et al., 2008, Sulmon et al., 2015). Factors such as the presence of refugia (Strachan et al., 2014) or the capability of recolonization after drought (Kim et al., 2014) could be responsible for different outcomes. On the one hand, some evidences on gastropods (Gérard et al., 2008) point to a relatively quick recovery of the assemblage after the drought breaks, but we have very little information on the role of resilience. On the other hand, the response of a community will probably increase with increasing frequency or duration of a perturbation (Fritz and Dodds, 2004). Therefore, we can expect differences between the effects of a single, short-term event and the effects of recurrent drying or long-term droughts. Much of the available literature come from short-term studies reporting assemblage characteristics before and immediately after a drought event sets in. The results obtained in this study can provide us with some useful information on the effects over longer periods. We found no relevant differences in richness between 2005 (before drought) and 2006 (after the first year of drought), but differences turned larger in 2014. Several possible explanations exist. Perhaps, the water-level reduction at the end of the summer 2005 may have not been high enough to induce changes in the assemblage. But an alternative explanation in the light of the resistance concept might be brought up. The assemblage might have remained unchanged (high resistance to disturbance) or have recovered (high resilience) in the first stages of the drought (2005-2006), but might be unable to fully recover after nine years of sustained summer drought. Further research and data from longer time series would be necessary to check this hypothesis. This apparent pattern, however, might be in accordance with the results provided by Jeffries (1994), who found reduced richness in the invertebrate communities of ponds after a five-year drought.

In summary, the results of this study seem to indicate that climatic change, with a probable increase of the intensity of summer droughts in many regions, might cause changes in littoral assemblages from permanent lakes, even if these droughts do not result in complete drying. The most likely and immediate effect might be a loss rather than a replacement of taxa. However, many questions relating the direct drivers of these changes and the ecological processes involved remain unsolved, including the roles of resistance and resilience.

Acknowledgements. This study has benefitted from the support of two research projects funded by the Government of Castilla y León (UMC1/04) and by the Spanish Ministry of Education and Science (CGL2006-03927). We want to thank David Bilton, Luis Felipe Valladares and David Miguélez for the identification of the species of Coleoptera.

\section{References}

Aroviita J, Hämäläinen H. 2008. The impact of water-level regulation on littoral macroinvertebrate assemblages in boreal lakes. Hydrobiologia 613: 45-56. 
Balogh C, Muskó IB, László G, Nagy L. 2008. Quantitative trends of zebra mussels in Lake Balaton (Hungary) in 2003-2005 at different water levels. Hydrobiologia 613: 57-69.

Baselga A. 2010. Partitioning the turnover and nestedness components of beta diversity. Glob Ecol Biogeogr 19: 134-143.

Baselga A, Orme D. 2012. betapart: an R package for the study of beta diversity. Methods Ecol Evol 3: 808-812.

Bauernfeind E, Soldán A. 2012. The Mayflies of Europe (Ephemeroptera). Denmark: Apollo Books, 781 p.

Bazzanti M, Seminara M, Baldoni S, Stella A. 2000. Macroinvertebrates and environmental factors of some temporary and permanent ponds in Italy. Verh Int Verein Limnol 27: 936-941.

Bazzanti M, Della Bella V, Seminara M. 2003. Factors affecting macroinvertebrate communities in astatic ponds in central Italy. J Freshw Ecol 18: 537-548.

Beklioglu M, Tan CO. 2008. Restoration of a shallow Mediterranean lake by biomanipulation complicated by drought. Fundam Appl Limnol/Arch Hydrobiol 171: 105-118.

Biggs J, Corfield A, Walker D, Whitfield M, Williams P. 1994. New approaches to the management of ponds. Br Wildl 5: 273-287.

Boix D, Gascón S, Sala J, Badosa A, Brucet S, López-Flores R, Martinoy M, Gifre J, Quintana XD. 2008. Patterns of composition and species richness of crustaceans and aquatic insects along environmental gradients in Mediterranean water bodies. Hydrobiologia 597(1): 53-69.

Boix D, García-Berthou E, Gascón S, Benejam L, Tornés E, Sala J, Benito J, Munné A, Solà C, Sabater S. 2010. Response of community structure to sustained drought in Mediterranean rivers. J Hydrol 383: 135-146.

Bond NR, Lake PS, Arthington AH. 2008. The impacts of drought on freshwater ecosystems: an Australian perspective. Hydrobiologia 600: 3-16.

Boulton AJ. 2003. Parallels and contrasts in the effects of drought on stream macroinvertebrate assemblages. Freshw Biol 48: 1173-1185.

Brock MA, Nielsen DL, Shiel RJ, Green JD, Langley JD. 2003. Drought and aquatic community resilience: the role of eggs and seeds in sediments of temporary wetlands. Freshw Biol 48: 1207-1218.

Céréghino R, Oertli B, Bazzanti M, Coccia C, Compin A, Biggs J, Bressi N, Grillas P, Hull A, Kalettka T, Scher O. 2012. Biological traits of European pond macroinvertebrates. Hydrobiologia 689: $51-61$.

Chase JM. 2007. Drought mediates the importance of stochastic community assembly. Proc Natl Acad Sci USA 104: 17430-17434.

Chessman BC. 2015. Relationships between lotic macroinvertebrate traits and responses to extreme drought. Freshw Biol 60: 50-63.

Čiamporová-Zatovičová Z, Hamerlík L, Šporka F, BituŠ́ík P. 2010. Littoral benthic macroinvertebrates of alpine lakes (Tatra Mts) along an altitudinal gradient: a basis for climate change assessment. Hydrobiologia 648: 19-34.

Collins MR, Knutti R, Arblaster J, Dufresne JL, Fichefet T, Friedlingstein P, Gao X, Gutowski WJ, Johns T, Krinner G, Shongwe M, Tebaldi C, Weaver AJ, Wehner M. 2013. Long-term climate change: projections, commitments and irreversibility. In: Stocker TF, Qin D, Plattner GK, Tignor M, Allen SK, Boschung J, Nauels A, Xia Y, Bex V, Midgley PM, eds. Climate change 2013: the physical science basis. Contribution of Working Group I to the Fifth Assessment Report of the Intergovernmental Panel on Climate Change. Cambridge, UK/New York: Cambridge University Press, pp. 1029-1136.

Collinson NH, Biggs J, Corfield A, Hodson MJ, Walker D, Whitfield M, Williams PJ. 1995. Temporary and permanent ponds: an assessment of the effects of drying out on the conservation value of aquatic macroinvertebrate communities. Biol Conserv 74: 125-133.
Colwell RK, Chao A, Gotelli NJ, Lin SY, Mao X, Chazdon RL, Longino JT. 2012. Models and estimators linking individual-based and sample-based rarefaction, extrapolation and comparison of assemblages. J Plant Ecol 5: 3-21.

Della Bella V, Bazzanti M, Chiarottif F. 2005. Macroinvertebrate diversity and conservation status of Mediterranean ponds in Italy: water permanence and mesohabitat influence. Aquat Conserv: Mar Freshw Ecosyst 15: 583-600.

Fritz KM, Dodds WK. 2004. Resistance and resilience of macroinvertebrate assemblages to drying and flood in a tallgrass prairie stream system. Hydrobiologia 527: 99-112.

Furey PC, Nordin RN, Mazumder A. 2006. Littoral benthic macroinvertebrates under contrasting drawdown in a reservoir and a natural lake. $J N$ Am Benthol Soc, 25, 19-31.

Galindo MD, Mata AJ, Mazuelos N, Serrano L. 1994. Microcrustacean and rotifer diversity and richness relating to water temporality in dune ponds of the Doñana National Park. Verh Int Ver Theor Angew Limnol 25: 1350-1356.

García-Criado F, Martínez-Sanz C, Valladares LF, Fernández-Aláez C. 2017. Environment and spatial patterns as drivers of littoral macroinvertebrate assemblages in patchily distributed mountain lakes: contribution to typology design. Limnologica 62: 57-67.

Gérard C. 2000. Dynamics and structure of a benthic macroinvertebrate community in a lake after drought. J Freshw Ecol 15(1): 65-69.

Gérard C. 2001. Consequences of a drought on freshwater gastropod and trematode communities. Hydrobiologia 459: 9-18.

Gérard C, Carpentier A, Paillisson J-M. 2008. Long-term dynamics and community structure of freshwater gastropods exposed to parasitism and other environmental stressors. Freshw Biol 53: 470-484.

Griswold MW, Berzinis RW, Crisman TL, Golladay SW. 2008. Impacts of climatic stability on the structural and functional aspects of macroinvertebrate communities after severe drought. Freshw Biol 53: 2465-2483.

Hsieh TC, Ma KH, Chao A. 2013. iNEXT online: interpolation and extrapolation (Version 1.3.0) [Software]. Available from http:// chao.stat.nthu.edu.tw/blog/software-download/.

James RT. 1991. Microbiology and chemistry of acid lakes in Florida: I. Effects of drought and post-drought conditions. Hydrobiologia 213: 205-225.

Jeffries M. 1994. Invertebrate communities and turnover in wetland ponds affected by drought. Freshw Biol 32: 603-612.

Kim DG, Lee CY, Choi LJ, Kang HJ, Baek MJ, Kim JG, Bae YJ. 2014. Drought effects on the colonization of benthic macroinvertebrate communities in the early successional phases in experimental mesocosm wetlands. J Freshw Ecol 29: 507-524.

Lake PS. 2003. Ecological effects of perturbation by drought in flowing waters. Freshw Biol 48: 1161-1172.

Lake PS. 2011. Drought and aquatic ecosystems: effects and responses. Oxford, UK: Wiley-Blackwell, $400 \mathrm{p}$.

Mackay F, Cyrus D, Russell K-L. 2010. Macrobenthic invertebrate responses to prolonged drought in South Africa's largest estuarine lake complex. Estuar Coast Shelf Sci 86: 553-567.

Martínez-Sanz C, Cenzano CS, Fernández-Aláez M, García-Criado F. 2012. Relative contribution of small mountain ponds to regional richness of littoral macroinvertebrates and the implications for conservation. Aquat Conserv: Mar Freshw Ecosyst 22(2): 155-164.

Millán A, Sánchez-Fernández D, Abellán P, Picazo F, Carbonell JA, Lobo JM, Ribera I. 2014. Atlas de los coleópteros acuáticos de España peninsular. Madrid: Ministerio de Agricultura, Alimentación y Medio Ambiente, 820 p. 
Nicolet P, Biigs J, Fox G, Hodson MJ, Reynolds C, Whitfield M, Williams P. 2004. The wetland plant and macroinvertebrate assemblages of temporary ponds in England and Wales. Biol Conserv 120: 261-278.

Nõges T, Nõges P. 1999. The effect of extreme water level decrease on hydrochemistry and phytoplankton in a shallow eutrophic lake. Hydrobiologia 408-409: 277-283.

Sahuquillo M, Miracle MR, Morata SM, Vicente M. 2012. Nutrient dynamics in water and sediment of Mediterranean ponds across a wide hydroperiod gradient. Limnologica - Ecol Manag Inland Waters 42: 282-290.

Seneviratne SI, Nicholls N, Easterling D, Goodess CM, Kanae S, Kossin J, Luo Y, Marengo J, McInnes K, Rahimi M, Reichstein M, Sorteberg A, Vera C, Zhang X. 2012. Changes in climate extremes and their impacts on the natural physical environment. In: Field CB, Barros V, Stocker TF, Qin D, Dokken DJ, Ebi KL, Mastrandrea MD, Mach KJ, Plattner GK, Allen SK, Tignor M, Midgley PM, eds. Managing the risks of extreme events and disasters to advance climate change adaptation. A special report of Working Groups I and II of the Intergovernmental Panel on Climate Change (IPCC). Cambridge, UK/New York: Cambridge University Press, pp. 109-230.

Solimini AG, Della Bella V, Bazzanti M. 2005. Macroinvertebrate size spectra of Mediterranean ponds with differing hydroperiod length. Aquat Conserv: Mar Freshw Ecosyst 15: 601-611.

Spencer M, Blaustein L, Schwartz SS, Cohen JE. 1999. Species richness and the proportion of predatory animal species in temporary freshwater pools: relationships with habitat size and permanence. Ecol Lett 2: 157-166.

Strachan SR, Chester ET, Robson BJ. 2014. Microrefuges from drying for invertebrates in a seasonal wetland. Freshw Biol 59: 2528-2538.
Sulmon C, van Baaren J, Cabello-Hurtado F, Gouesbet G, Hennion F, Mony C, Renault D, Bormans M, El Amrani A, Wiegand C, Gérard C. 2015. Abiotic stressors and stress responses: what commonalities appear between species across biological organization levels? Environ Pollut 202: 66-77.

Tierno de Figueroa JM, Sánchez-Ortega A, Membiela Iglesia P, Luzón-Ortega JM. 2003. Fauna Ibérica. Plecoptera. Madrid: Consejo Superior de Investigaciones Científicas, vol. 22, 408 p.

Wantzen K, Junk W, Rothhaupt K-O. 2008. An extension of the floodpulse concept (FPC) for lakes. In: Wantzen K, Rothhaupt K-O, Mörtl M, Cantonati M, Tóth LG, Fischer P, eds. Ecological effects of water-level fluctuations in lakes SE-15. Netherlands: Springer, pp. 151-170.

Waterkeyn A, Grillas P, Vanschoenwinkel B, Brendonck LUC. 2008. Invertebrate community patterns in Mediterranean temporary wetlands along hydroperiod and salinity gradients. Freshw Biol 53: 1808-1822.

Werner S, Rothhaupt K-O. 2008. Mass mortality of the invasive bivalve Corbicula fluminea induced by a severe low-water event and associated low water temperatures. Hydrobiologia 613: $143-150$.

White MS, Xenopoulos MA, Hogsden K, Metcalfe RA, Dillon PJ. 2008. Natural lake level fluctuation and associated concordance with water quality and aquatic communities within small lakes of the Laurentian Great Lakes region. Hydrobiologia 613: 21-31.

Wissinger SA, Oertli B, Rosset V. 2016. Invertebrate communities of alpine ponds. In: Batzer D, Boix D, eds. Invertebrates in freshwater wetlands. An international perspective on their ecology. Switzerland: Springer, pp. 55-103.

Woodward G, Perkins DM, Brown LE. 2010. Climate change and freshwater ecosystems: impacts across multiple levels of organization. Philos Trans R Soc Lond B: Biol Sci 365: 2093-2106.

Cite this article as: Villastrigo A, García-Criado F. 2017. Response of a littoral macroinvertebrate assemblage to a persistent hydrological drought in a permanent mountain shallow lake from northwestern Spain. Ann. Limnol. - Int. J. Lim. 53: 315-323 


\section{Appendices}

Appendix. Species list with abundance data (individuals per minute sampling).

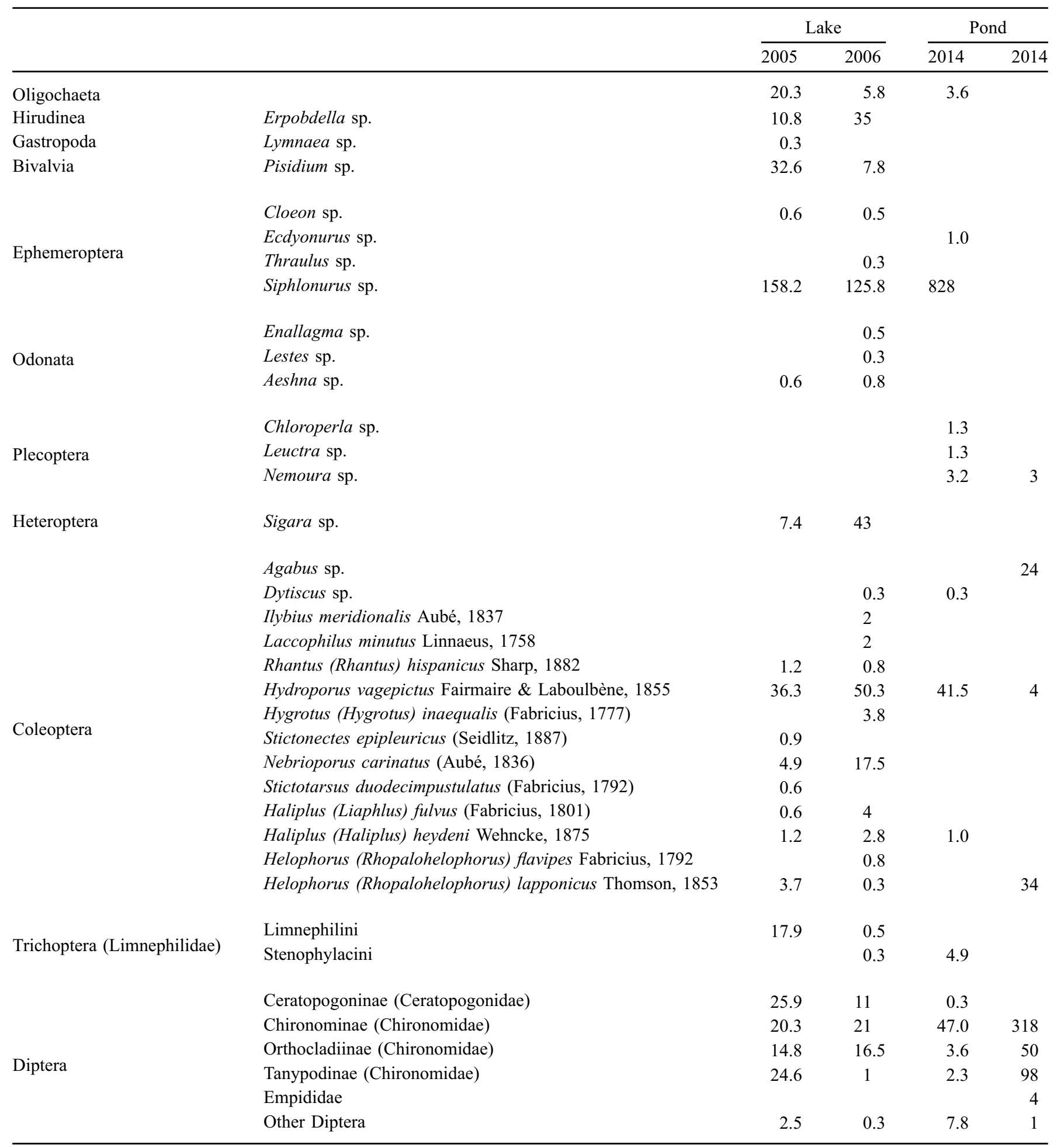

